DOI:10.22337/2587-9618-2018-14-3-68-82

\title{
ARCHITECTURAL MODELLING OF “SOUND” PERGOLA
}

\author{
Valery S. Lesovik, Irina L. Pershina, Dmitry Yu. Popov, \\ Andrey V. Shevchenko
}

Belgorod State Technological University named after V.G. Shukhov, Belgorod, RUSSIA

\begin{abstract}
The article describes architectural solutions of pergolas adapted for the reproduction of synthesized acoustic space. The solution is represented by means of computer modelling and visualizes both processes and objects on the example of construction and calculations. The project design of architectural models is an integral part in the practical reconstruction of the geospatial space studied by the architectural geography.
\end{abstract}

Keywords: architectural geonics, computer modelling, specific space, acoustic architectural environment, textiles-concrete, reinforcement, composite binder

\section{АРХИТЕКТУРНОЕ МОДЕЛИРОВАНИЕ «ЗВУКОВОЙ» ПЕРГОЛЫ}

\author{
В.С. Лесовик, И.Л. Першина, Д.Ю. Попов, А.В. Шевченко \\ Белгородский государственный технологический университет им. В.Г. Шухова, г. Белгород, РОССИЯ
}

\begin{abstract}
Аннотация: В статье описаны архитектурные решения перголы, приспособленной для воспроизводства сентезированного акустического пространства. Решение представлено средствами компьютерного моделирования и визуализирует как процессы, так и объекты на примере построения и расчетов. Проектная разработка архитектурных моделей является неотъемлемой частью в практическом воссоздании исследуемого архитектурной геоникой геоспецифического пространства.
\end{abstract}

Ключевые слова: архитектурная геоника, компьютерное моделирование, специфическое пространство, акустическая архитектурная среда, текстиль-бетон, армирование, композиционное вяжущее

\section{INTRODUCTION. ABOUT THE PROCESS CONTENT OF THE COMPOSITION}

Denoting the problem of creating an architectural environment that exerts a therapeutic intervention on the physical and psychoemotional state of a person, a solution appears to be a fundamentally new way of solving an actual scientific problem. The originality of the formulated approaches allows us to talk about a new paradigm in architecture - architectural geonics [1-3], which formulates the systematic study of the influence of geofactors on humans and has in its deposit tools for creating specificity of space [4-5].

Modern trends of transdisciplinarity in the theory and practice of architectural geology [6], expressed in separate concepts, methods and approaches, are "supported" by the latest knowledge and indicate the development of the vector of geodirectional architecture. Their local manifestations reflect a comprehensive approach to creating a positive architectural and spatial living environment. This confirms the need for the development of architectural geology in the framework of theoretical and project experience in the formation of geo-approaches, as well as the development of principles and models of geosynthetically specific space.

The results presented in this paper are an architectural part of the implementation of the experiment on the practical implementation of the idea of creating an acoustic environment as a form of representation of an architectural space, according to A.G. Rappaport formulation, one of the types of "perceptual real space, reflected by human perception" [7]. 
As a model of an architectural specific space, two sketches are implemented, developing ideas for the conceptual shaping of structures for various purposes. The specificity of space in all cases is monosyllabic: one geosynthetized tool of architectural geography using the possibilities of air flows was applied.

The aim is to erect a "sound" surface for practical modelling of a specific medium by means of architectural geography within the framework of scientific research.

At the preparatory stage of the practical solution of this problem, the search and systematization of architectural analogs were carried out; on the basis of this stage, the development of conceptual design proposals for sound architectural structures that form the geospecific nature of space through the application of methods of computer modelling of structures and objects. The possibilities of modern software tools for analyzing and designing the concepts of sound spaces were limited to the ArchiCad, 3-Ds Max, SketchUp programs and the Lumion 3D animation visualization program. As an opportunity to implement it is proposed to use the products of scientific developments of post-graduate students and scientists of BSTU named after V.G. Shukhov. They initiated the research of a nontraditional material for Russian construction textile-concrete. Textile-concrete is a composite material, consisting, like ordinary reinforced concrete, of concrete and reinforcement, but instead of steel reinforcement, alkali-resistant glass fibers or carbon fibers are used.

\section{ARCHITECTURE MODELS}

The conceptual proposal is a geological model of the "sound" pergola (Figure 1). The proposed small form is located in Belgorod, on the territory of BSTU named after V.G. Shukhov. The pergola is a lattice black and shade canopy on three visually massive supports (Figure 2 and Figure 3). According to the calculations below, the geometric dimensions of the pergola in the plan are $41.00 \times 33.00 \mathrm{~m}$ (Figure 4$)$. The shape in the plan is triangular, with radially rounded ends. The lattice structure has a height of 200$600 \mathrm{~mm}$ with a cell size of $300 \times 300 \mathrm{~mm}$. The conditional plane of the pergola canopy has a complicated concave surface of different heights (within $600 \mathrm{~mm}$ ).

The expediency of such geometric data is due to the possibility of arbitrary placement of pipes / tubes to create sounds of various required frequencies. The optimal outer diameter of the pipes is $300 \mathrm{~mm}$. In this case, it is possible to place pipes of any larger diameter multiple of $300 \mathrm{~mm}$ by cutting a cross-shaped segment of a pergola structure for a diameter of $600 \mathrm{~mm}$ or cutting a $900 \times 900 \mathrm{~mm}$ grating segment to mount a $900 \mathrm{~mm}$ diameter pipe.

The concept of sound pergola technology is to form the whole structure with the help of textiles-concrete, described in the section "Applied Materials" of this article.

The estimated height in the span is $4,00-5,00$ $\mathrm{m}$. The maximum height of the structure is 5,00 $-6,60 \mathrm{~m}$. The sound pipes are metal.

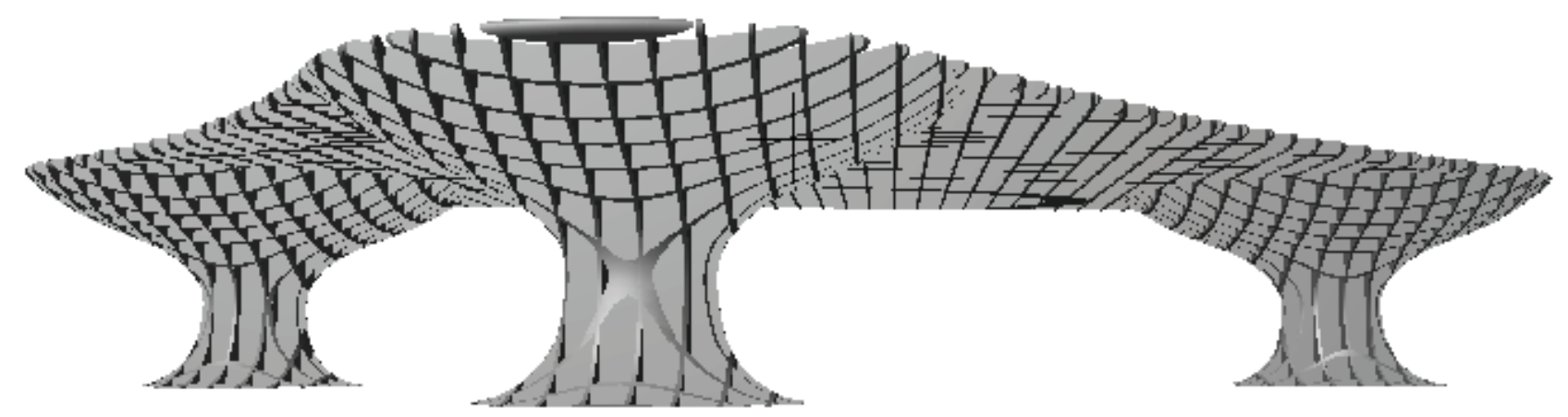

Figure 1. Three-dimensional model of pergola from height of human scale. 


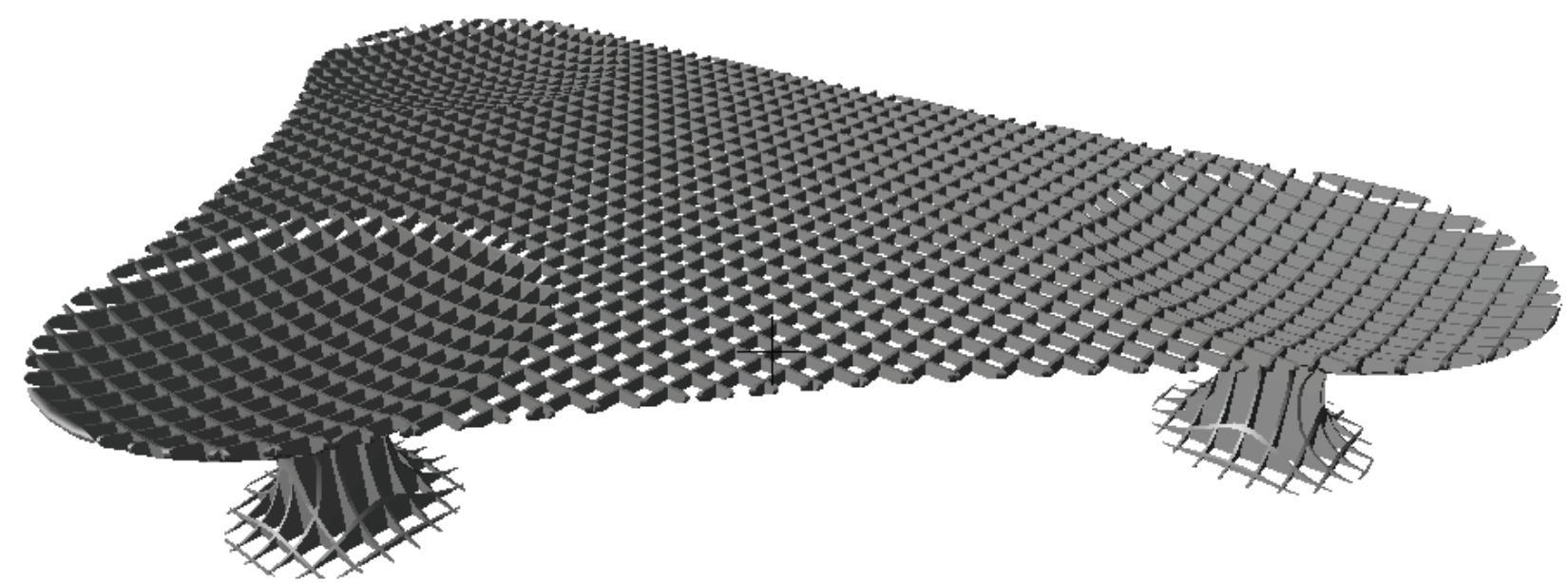

Figure 2. Three-dimensional model of pergola with high chamber height.

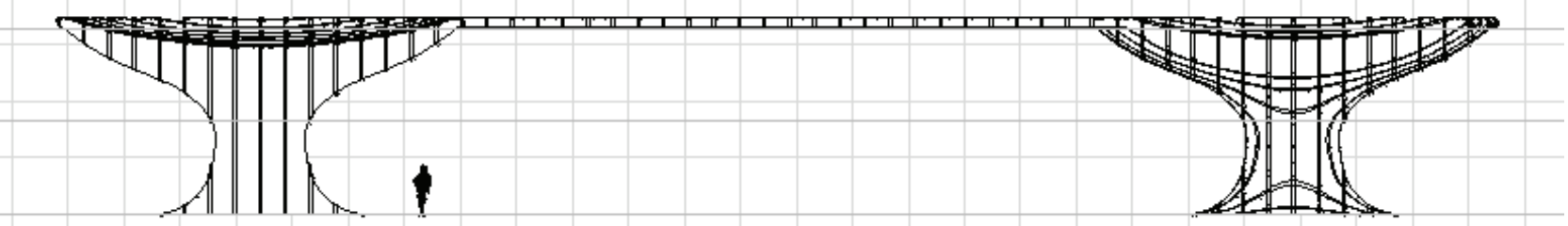

Figure 3. Orthogonal projection of the façade.

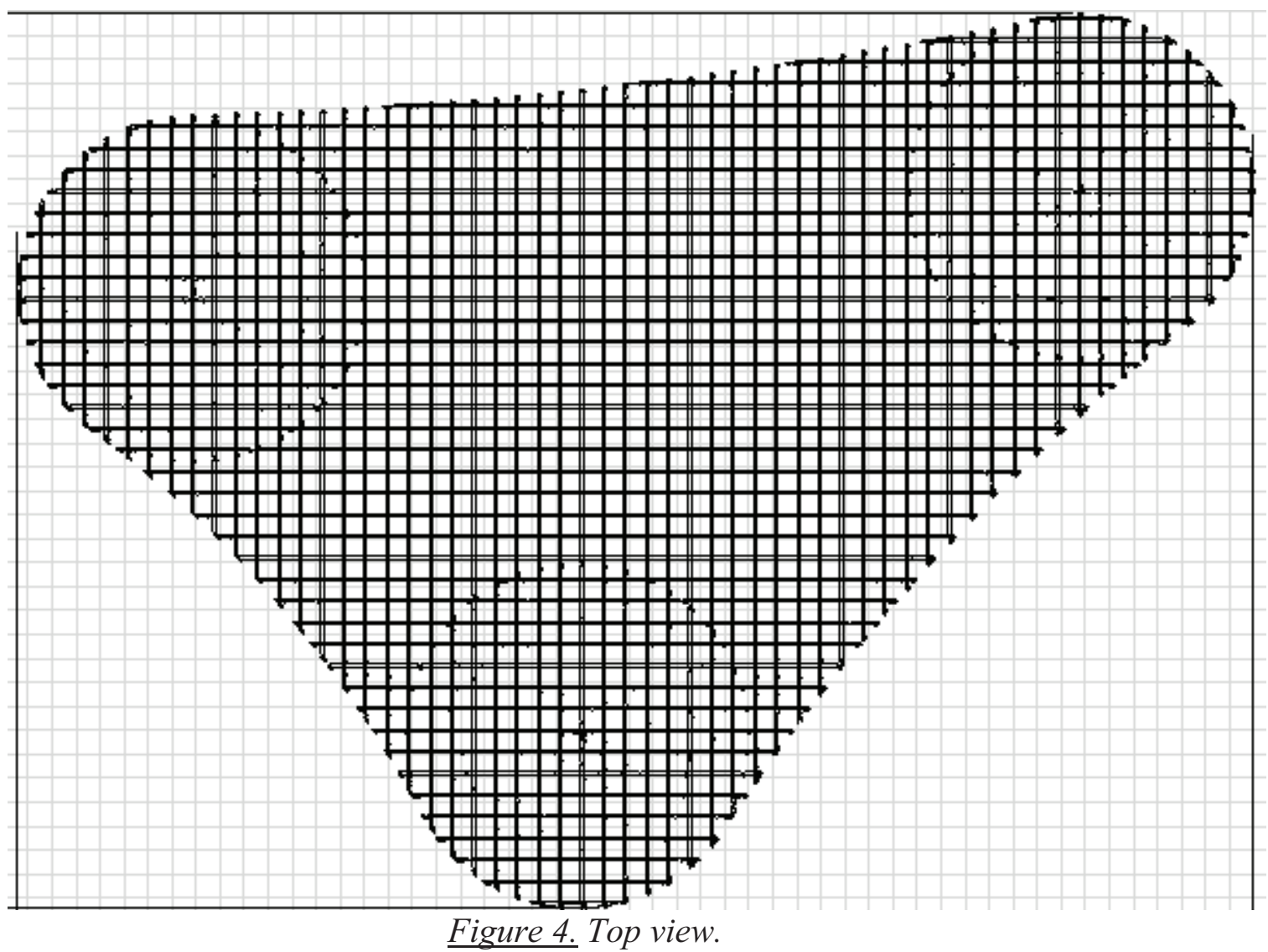




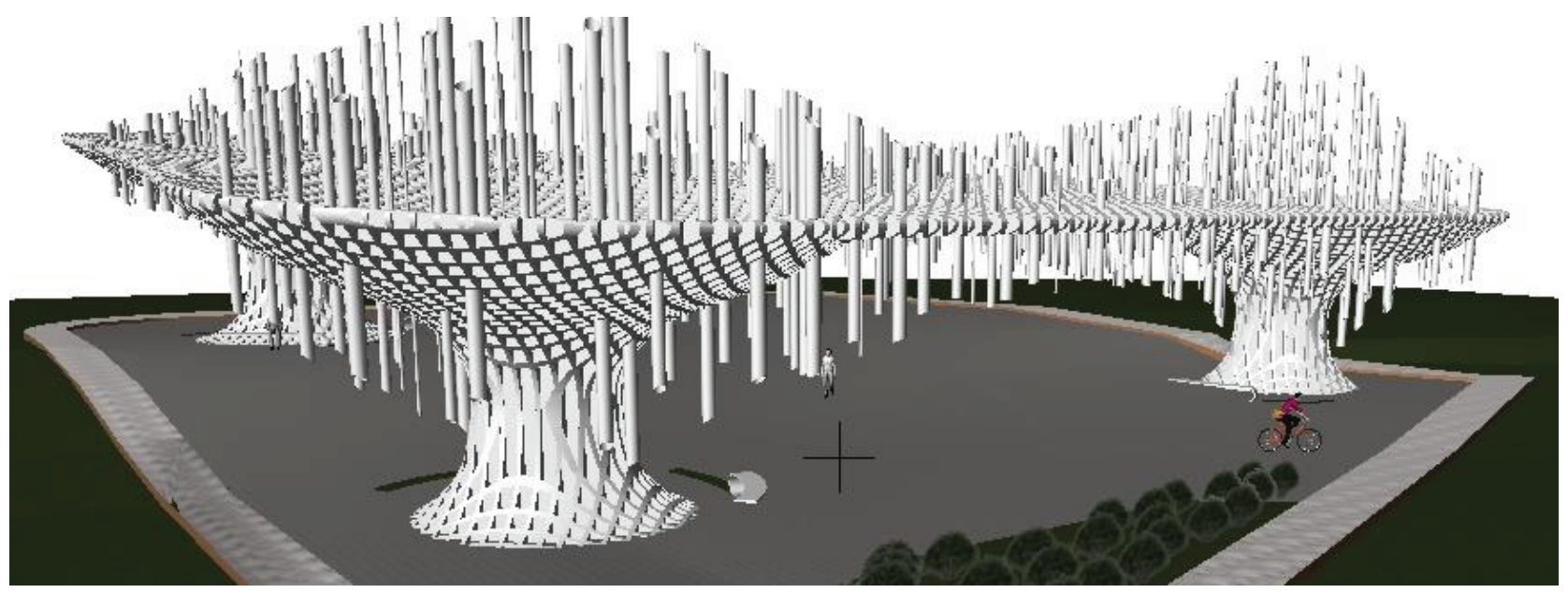

Figure 5. Perspective view of the pergola with the placement of sound tubes.

The initial stage of pergola design involves the search for alternative solutions for support. Acceptable variants in the form of abstract forms are given in Table 1. The shape of each model dictates its own, spatial compatibility of supports, acceptable only for this variant. The optimality of the constructive solution is confirmed by numerical calculations.

Simulation of the lower part of the support (Table 2) assumes design and pragmatism in operation, for example, a reduction in the number of potential places of accumulation of debris and the availability of seats for people.

Theoretical propositions of some design solutions for the creation of sound spaces based on the analysis of the use of the experience of extraction of sounds in wind instruments, set forth in the report and in a published article [8] in the section "Architectural Geonics" of the International Online Congress "Fundamentals of Building Materials Science" (BSTU named after V.G. Shukhov, 2017), allow us to compile the theme of a sound specific environment through the analogy of sound extraction from musical instruments, such as wind and string.

The use of methods for creating musical tones on such instruments will make it possible to repeat the features of sound formation in geological installations, thereby creating the possibility of studying the emotional responses of a person caused by the sound specificity of an architectural space. And this can be considered a modelling of the form of a specific medium by means of architectural geonics.

The analysis of the medical factors of the sound effect on the endogenous rhythms of the organism [9-10] confirms the influence of a specific architectural environment on the creation of a psychological climate [11], the generation of positive emotions, creative mood, and mental activity. And gives a scientific justification of the therapeutic properties of the ecologicalphysiological method of impact by an acoustic method by quantitative and qualitative assessment of the factors of their optimizing effect.

\section{MATERIALS EMPLOYED}

To create a new architectural environment, conceptually new efficient building materials are needed, which allow creating complex filigree forms that ensure ease of operation and safety during operation. Attractive from this point of view is a textile-reinforced composite material - textiles-concrete $[12,13]$. At present, the composite is widely used in a number of European countries and has established itself as a universal high-quality material [14-16]. To create a "sound" pergola, it is proposed to use textile-concrete of increased efficiency, the composition of which is specially selected taking into account the peculiarities of the local raw materials used, the method of preparation and optimization of the processes of structure 
Table 1. Modelling of the abstract form of pergola support.

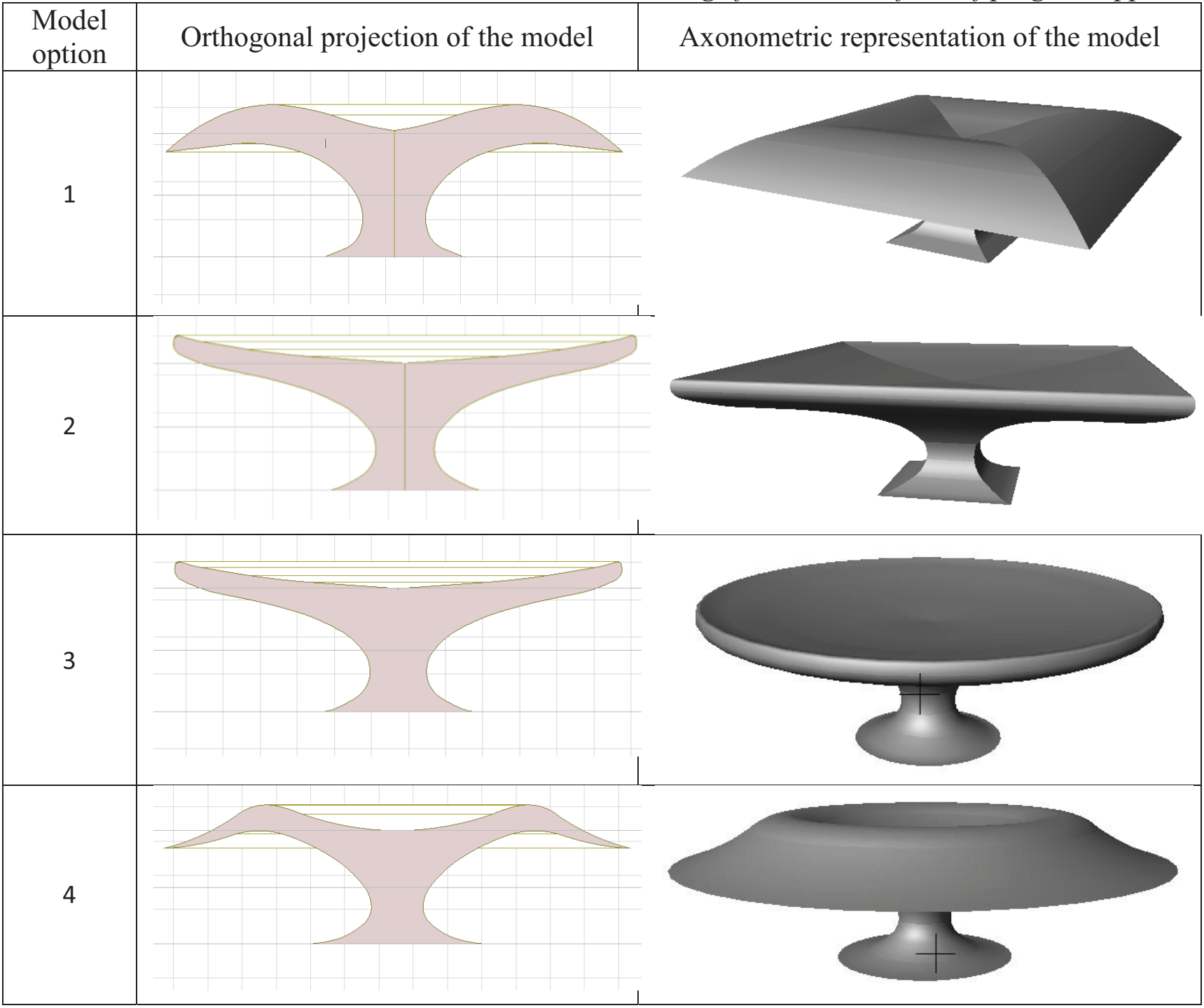

formation due to application of composite binder properties $[17,18]$. The characteristics of the materials used are presented in Table 3. The use of composite binders allows to obtain a new generation of material with high physicalmechanical and operational characteristics that are unattainable with the use of traditional raw materials and will ensure a qualitative structure formation of the material.

The composite binder is prepared by the joint grinding of cement and waste of wet magnetic separation (WMSW) to a specific surface of 550 $\mathrm{m}^{2} / \mathrm{kg}$ and optimized by the optimum amount of superplasticizer.
Optimization of the processes of structure formation of composite binders is due to the successive growth of neoplasms during the hardening of the system "clinker minerals - quartz of different origins of WMSW - watersuperplasticizer waste", due to the different intensity and time of interaction of polygenetic quartz with the products of hydration of clinker minerals.

Selection of the rational composition of the filler mixture is carried out by the method of calculation of high-density packages [19]. The characteristic of the proposed composition of finegrained concrete is presented in Table 4. 
Table 2. Simulation of the lower part of the pergola.

\begin{tabular}{|l|c|c|}
\hline $\begin{array}{c}\text { Model } \\
\text { option }\end{array}$ & $\begin{array}{c}\text { Orthogonal projection of the lower part } \\
\text { of the model }\end{array}$ & $\begin{array}{c}\text { Axonometric view of the bottom part } \\
\text { of the model }\end{array}$ \\
\hline 1 & \\
\hline
\end{tabular}

Table 3. Characteristics of the materials used.

\begin{tabular}{|c|c|c|c|}
\hline Denomination & Deposit & Dispersability & $\begin{array}{l}\text { True specific gravity, } \\
\qquad \mathrm{kg} / \mathrm{m}^{3}\end{array}$ \\
\hline Sand & $\begin{array}{l}\text { "Klinovec" quarry, } \\
\text { Senevskoe deposit, } \\
\text { Korochansky district }\end{array}$ & $0,16-0,63 \mathrm{~mm}$ & 2630 \\
\hline Cement & $\begin{array}{c}\text { ZAO "Belgorodsky } \\
\text { Cement" }\end{array}$ & $330 \mathrm{~m}^{2} / \mathrm{kg}$ & 3100 \\
\hline $\begin{array}{l}\text { Wet Magnetic Separation } \\
\text { Waste (WMSW) }\end{array}$ & $\begin{array}{l}\text { Lebedinsky GOK, } \\
\text { Gubkin }\end{array}$ & $85 \mathrm{~m}^{2} / \mathrm{kg}$ & 2800 \\
\hline Crushed sand & $\begin{array}{l}\text { "Klinovec" quarry, } \\
\text { Senevskoe deposit, } \\
\text { Korochansky district }\end{array}$ & $200 \mathrm{~m}^{2} / \mathrm{kg}$ & 2630 \\
\hline Glenium-51 & & Liquid & $1,13-1,15 \mathrm{~kg} / \mathrm{dm}^{3}$ \\
\hline
\end{tabular}

\section{NUMERICAL IMPLEMENTATION OF THE CONSTRUCTION}

As a design scheme, we take a spatial core system with a span of $22 \mathrm{~m}$. The cell step is $300 \times$ $300 \mathrm{~mm}$. The physical nonlinearity of the materials is first taken as an exponential dependence.
Concrete is heavy, fine-grained, class B20 $\left(\mathrm{E}_{\mathrm{b}}=\right.$ $27500 \mathrm{MPa}, \mathrm{R}_{\mathrm{b}}$, ser $\left.=15 \mathrm{MPa}\right)$. AR-glass $(120$ $\mathrm{g} / \mathrm{m}^{2}, 2 \mathrm{D}$, Bewehrung Typ 11, $\mathrm{E}_{\mathrm{f}}=72,000 \mathrm{MPa}$, $\mathrm{Rf}, \mathrm{n}=1450 \mathrm{MPa}, \mathrm{A}_{\mathrm{f}}=7.07 \mathrm{~mm}^{2}$ ) was used as the reinforcing material. The bending moment in the section (for the III snow region) $\mathrm{M}=0.83$ $\mathrm{kNm}$. 
Table 4. Characteristics of the cement matrix of textile-concrete.

\begin{tabular}{|l|l|l|l|}
\hline \multicolumn{1}{|c|}{ Denomination } & \multicolumn{1}{c|}{ Condition } & \multicolumn{1}{c|}{ Unit } & \multicolumn{1}{c|}{ Value } \\
\hline Fresh mortar stiffness & & $\mathrm{kg} / \mathrm{m}^{3}$ & 2400 \\
\hline Elapsed time & at $+20^{\circ} \mathrm{C}$ & $\mathrm{min}$ & $\approx 60$ \\
\hline Spread in accordance with DIN & $5 \mathrm{~min}$ & $\mathrm{~cm}$ & $\geq 17$ \\
EN 1015-3 & $30 \mathrm{~min}$ & $\mathrm{~cm}$ & $\geq 14$ \\
\hline $\begin{array}{l}\text { Compressive strength } \\
\text { in accordance with GOST 10180, } \\
\text { prisms } 4 \times 4 \times 16 \mathrm{~cm}\end{array}$ & $24 \mathrm{~h}$ full days & $\mathrm{MPa}$ & $\geq 15$ \\
\hline $\begin{array}{l}\text { Bending strength in accordance } \\
\text { with GOST } 10180,\end{array}$ & 28 full days & $24 \mathrm{hPa}$ & $\geq 80$ \\
prisms $4 \times 4 \times 16 \mathrm{~cm}$ & 7 full days & $\mathrm{MPa}$ & $\geq 3$ \\
\hline Modulus of elasticity & 28 full days & & $\geq 6$ \\
\hline
\end{tabular}

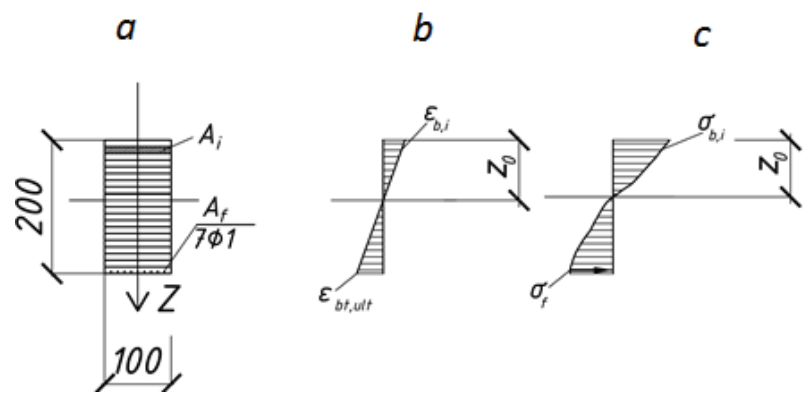

Figure 6. For example of crack resistance calculation: $a$ - the design scheme of the section; $b$ - diagram of relative deformations; $c$ - stress diagram.
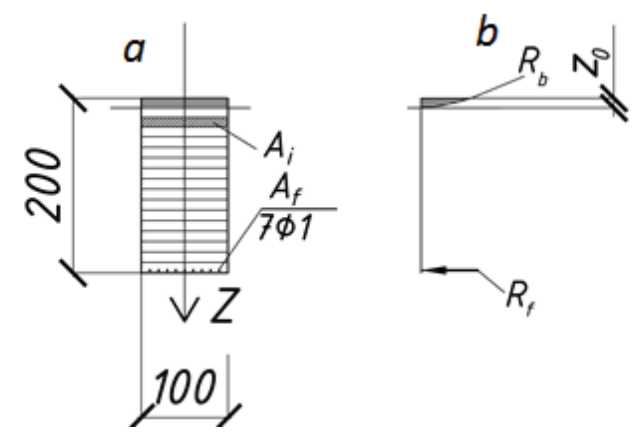

Figure 7. For example of strength calculating: $a$ - the design scheme of the section; $b$-stress diagram.

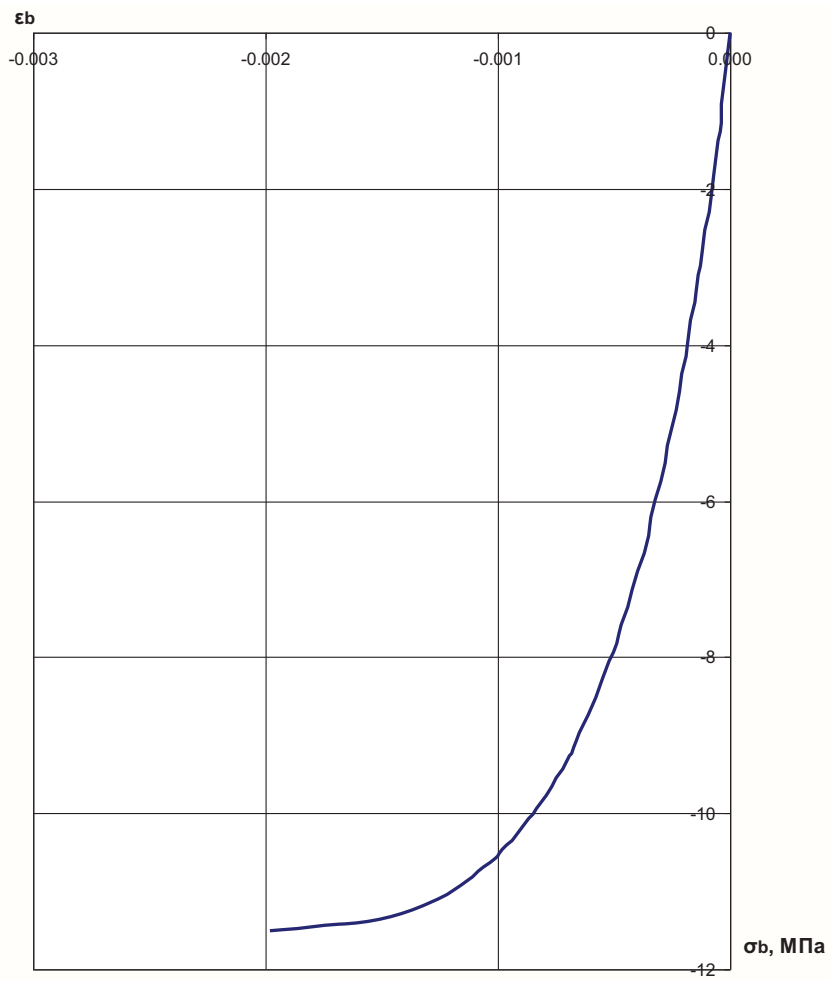

Figure 8. Concrete deformation diagram for strength calculation. 


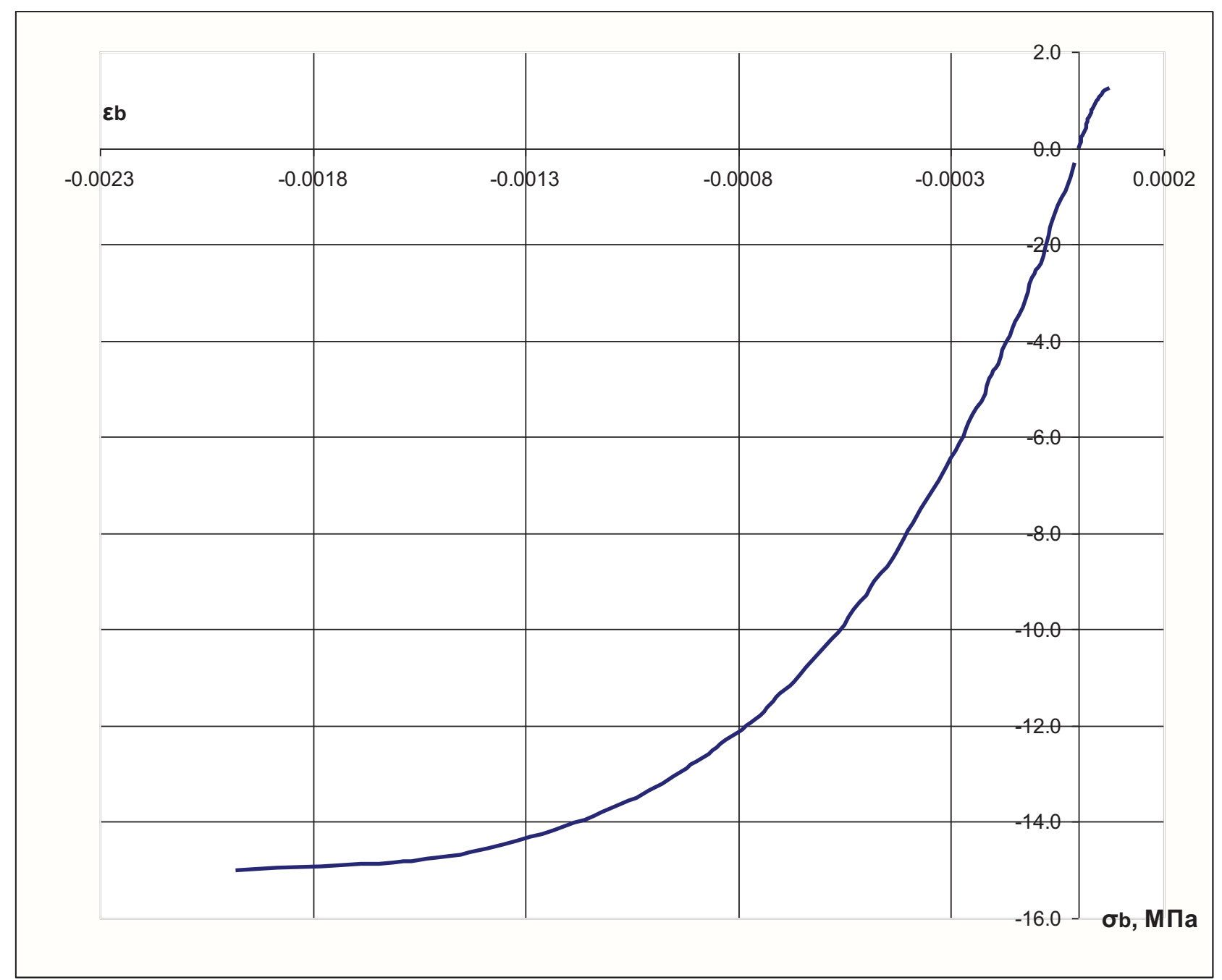

Figure 9. The diagram of the deformation of concrete for the calculation of the second group of limit states.

The results of calculating the strength and fracture toughness are given in Tables 5 and 6. The minimum cross-section of the structure was previously taken at $100 \times 200(\mathrm{~h}) \mathrm{mm}$. In the calculation, we consider the work of only the fly-through part of the pergola. The calculation is carried out according to the procedure [20] on the basis of the nonlinear deformation model of concrete (Figures 6-9), and also taking the proportional dependence of the deformation of the reinforcing material.

The limiting moment, perceived by the cross section, is $\mathrm{M}_{\mathrm{ult}}=1,41 \cdot 10^{6} \mathrm{Nmm}=1,41 \mathrm{kNm}$. The relative error in the calculations was $7 \%$.
The crack resistance moment $\mathrm{M}_{\mathrm{crc}}=1.08 \cdot 10^{6}$ $\mathrm{Nmm}=1.08 \mathrm{kNm}$ (calculated with a relative error of $2 \%$ ). The limiting load, perceived by the cross section $\mathrm{M}_{\mathrm{crc}}=1.08 \mathrm{kNm}>\mathrm{M}=0.83$ $\mathrm{kNm}$. Tables 5 and 6 show the results of calculating the strength and crack resistance of the normal section: strength and crack resistance are provided.

Based on the results of calculating the structural strength of one element of a triangular shaped canopy of "sonic" pergola, the following textileconcrete construction is proposed to provide the required strength (Table 7 ). 
Valery S. Lesovik, Irina L. Pershina, Dmitry Yu. Popov, Andrey V. Shevchenko

Table 5. Results of calculating the strength of a normal section.

\begin{tabular}{|c|c|c|c|c|c|c|c|c|c|c|c|c|c|}
\hline $\begin{array}{l}\text { Sec- } \\
\text { tion } \\
\text { num } \\
\text { ber }\end{array}$ & $\begin{array}{l}\text { Plott } \\
\text { age, } \\
\mathrm{mm}^{2}\end{array}$ & $\begin{array}{c}\mathrm{Co} \\
\text { ordi } \\
\text { nat } \\
\mathrm{e} \\
\mathrm{Z}_{\mathrm{b}} \\
\mathrm{MM}\end{array}$ & $\begin{array}{c}\text { Co } \\
\text { ordi } \\
\text { nat } \\
\text { e } \\
\mathrm{Z}_{\mathrm{f}} \text {, } \\
\mathrm{MM}\end{array}$ & $\varepsilon_{i}$ & $\begin{array}{l}\mathrm{E}_{\mathrm{b}, \mathrm{i}} \\
\mathrm{M \Pi а}\end{array}$ & $\begin{array}{c}\sigma_{b i} \\
\text { MПa }\end{array}$ & $\begin{array}{c}\mathrm{E}_{\mathrm{f}, \mathrm{i}} \\
\mathrm{MПа}\end{array}$ & $\begin{array}{c}\sigma_{\mathrm{fi}}, \\
\mathrm{M}\end{array}$ & $\begin{array}{c}1 / \rho, \\
\mathrm{MM}^{-1}\end{array}$ & $\begin{array}{c}\varepsilon_{\mathrm{b}, \mathrm{u}} \\
1 \mathrm{t}\end{array}$ & $\begin{array}{l}\mathrm{ZO}, \\
\mathrm{MM}\end{array}$ & $\sigma_{\mathrm{i} \cdot \mathrm{Ai}}$ & $\begin{array}{c}\sigma_{\mathrm{i} \cdot \mathrm{Ai}} \\
\mathrm{Z}_{\mathrm{i}}\end{array}$ \\
\hline 1 & 2 & 3 & 4 & 5 & 6 & 7 & 8 & 9 & 10 & 11 & 12 & 13 & 14 \\
\hline 1 & 275 & $\begin{array}{c}- \\
9.62 \\
5\end{array}$ & & $\begin{array}{c}- \\
0.00 \\
198\end{array}$ & 5808.1 & -11.500 & & & & & & -3163 & 30439 \\
\hline 2 & 275 & $\begin{array}{c}- \\
6.87 \\
5\end{array}$ & & $\begin{array}{c}- \\
0.00 \\
057\end{array}$ & 14929.8 & -8.510 & & & & & & -2340 & 16089 \\
\hline 3 & 275 & $\begin{array}{c}- \\
4.12 \\
5\end{array}$ & & $\begin{array}{c}- \\
0.00 \\
034\end{array}$ & 18264.7 & -6.210 & & & & & & -1708 & 7044 \\
\hline 4 & 275 & $\begin{array}{c}- \\
1.37 \\
5\end{array}$ & & $\begin{array}{c}- \\
0.00 \\
011\end{array}$ & 23000 & -2.530 & & & & & & -696 & 957 \\
\hline 5 & 1100 & $5 . .5$ & & $\begin{array}{l}0.00 \\
046\end{array}$ & 0 & 0.000 & & & & & & 0 & 0 \\
\hline 6 & 1100 & 16.5 & & $\begin{array}{l}0.00 \\
137\end{array}$ & 0 & 0.000 & & & & & & 0 & 0 \\
\hline 7 & 1100 & 27.5 & & $\begin{array}{l}0.00 \\
228\end{array}$ & 0 & 0.000 & & & & & & 0 & 0 \\
\hline 8 & 1200 & 39.5 & & $\begin{array}{l}0.00 \\
328\end{array}$ & 0 & 0.000 & & & & & & 0 & 0 \\
\hline 9 & 1200 & 51.5 & & $\begin{array}{l}0.00 \\
428\end{array}$ & 0 & 0.000 & & & $\begin{array}{c}8.30 \mathrm{E}- \\
05\end{array}$ & $\begin{array}{l}0.00 \\
198\end{array}$ & 11.0 & 0 & 0 \\
\hline 10 & 1200 & 63.5 & & $\begin{array}{l}0.00 \\
527\end{array}$ & 0 & 0.000 & & & & & & 0 & 0 \\
\hline 11 & 1200 & 75.5 & & $\begin{array}{l}0.00 \\
627 \\
\end{array}$ & 0 & 0.000 & & & & & & 0 & 0 \\
\hline 12 & 1200 & 87.5 & & $\begin{array}{l}0.00 \\
727\end{array}$ & 0 & 0.000 & & & & & & 0 & 0 \\
\hline 13 & 1200 & 99.5 & & $\begin{array}{l}0.00 \\
826\end{array}$ & 0 & 0.000 & & & & & & 0 & 0 \\
\hline 14 & 1200 & $\begin{array}{c}111 . \\
5\end{array}$ & & $\begin{array}{l}0.00 \\
926\end{array}$ & 0 & 0.000 & & & & & & 0 & 0 \\
\hline 15 & 1200 & $\begin{array}{c}123 . \\
5\end{array}$ & & $\begin{array}{l}0.01 \\
026\end{array}$ & 0 & 0.000 & & & & & & 0 & 0 \\
\hline 16 & 1200 & $\begin{array}{c}135 . \\
5\end{array}$ & & $\begin{array}{l}0.01 \\
125\end{array}$ & 0 & 0.000 & & & & & & 0 & 0 \\
\hline 17 & 1200 & $\begin{array}{c}147 . \\
5\end{array}$ & & $\begin{array}{l}0.01 \\
225\end{array}$ & 0 & 0.000 & & & & & & 0 & 0 \\
\hline 18 & 1200 & $\begin{array}{c}159 . \\
5\end{array}$ & & $\begin{array}{l}0.01 \\
325\end{array}$ & 0 & 0.000 & & & & & & 0 & 0 \\
\hline 19 & 1200 & $\begin{array}{c}171 . \\
5\end{array}$ & & $\begin{array}{l}0.01 \\
424\end{array}$ & 0 & 0.000 & & & & & & 0 & 0 \\
\hline 20 & 1200 & $\begin{array}{c}183 . \\
5\end{array}$ & & $\begin{array}{l}0.01 \\
524 \\
\end{array}$ & 0 & 0.000 & & & & & & 0 & 0 \\
\hline 21 & 7.07 & & $\begin{array}{c}185 . \\
5\end{array}$ & $\begin{array}{l}0.01 \\
438 \\
\end{array}$ & & & $\begin{array}{c}72000.0 \\
00\end{array}$ & 1035.71 & & & & 7323 & $\begin{array}{c}13583 \\
24\end{array}$ \\
\hline & & & & & & & & & & & $\Sigma=$ & -584 & $\begin{array}{c}14128 \\
53\end{array}$ \\
\hline
\end{tabular}


Table 6. Results of calculation of fracture toughness of normal section.

\begin{tabular}{|c|c|c|c|c|c|c|c|c|c|c|c|c|c|}
\hline $\begin{array}{l}\text { Sect } \\
\text { ion } \\
\text { num } \\
\text { ber }\end{array}$ & $\begin{array}{l}\text { Plot- } \\
\text { tage, } \\
\mathrm{mm}^{2}\end{array}$ & $\begin{array}{c}\mathrm{Co} \\
\text { ordi } \\
\text { nat } \\
\mathrm{e} \\
\mathrm{Z}_{\mathrm{b}} \\
\mathrm{MM}\end{array}$ & $\begin{array}{c}\text { Co } \\
\text { ord } \\
\text { ina } \\
\text { te } \\
\mathrm{Z}_{\mathrm{f}}, \\
\mathrm{MM}\end{array}$ & $\varepsilon_{i}$ & $\begin{array}{l}\mathrm{E}_{\mathrm{b}, \mathrm{i}} \\
\mathrm{M \Pi а}\end{array}$ & $\begin{array}{c}\sigma_{\mathrm{bi}} \\
\mathrm{M \Pi а}\end{array}$ & $\begin{array}{c}\mathrm{E}_{\mathrm{f}, \mathrm{i}} \\
\mathrm{M \prod а}\end{array}$ & $\begin{array}{c}\sigma_{\mathrm{fi}}, \\
\mathrm{M} \mathrm{Ia}\end{array}$ & $\begin{array}{c}1 / \rho, \\
\mathrm{MM}^{-1}\end{array}$ & $\begin{array}{c}\varepsilon_{\mathrm{b}} \\
\mathrm{t}, \mathrm{ul} \\
\mathrm{t}\end{array}$ & $\begin{array}{l}\mathrm{ZO}, \\
\mathrm{MM}\end{array}$ & $\sigma_{\mathrm{i} \cdot \mathrm{Ai}}$ & $\sigma_{\mathrm{i} \cdot \mathrm{Ai} \cdot \mathrm{Zi}}$ \\
\hline 1 & 1000 & -90.5 & & $\begin{array}{c}- \\
0.0000 \\
6\end{array}$ & 26217 & -1.573 & & & & & & -1573 & 142357 \\
\hline 2 & 1000 & -80.5 & & $\begin{array}{c}- \\
0.0000 \\
6\end{array}$ & 26217 & -1.573 & & & & & & -1573 & 126627 \\
\hline 3 & 1000 & -70.5 & & $\begin{array}{c}- \\
0.0000 \\
5\end{array}$ & 26480 & -1.324 & & & & & & -1324 & 93342 \\
\hline 4 & 1000 & -60.5 & & $\begin{array}{c}- \\
0.0000 \\
4\end{array}$ & 26775 & -1.071 & & & & & & -1071 & 64796 \\
\hline 5 & 1000 & -50.5 & & $\begin{array}{c}- \\
0.0000 \\
3\end{array}$ & 27067 & -0.812 & & & & & & -812 & 41006 \\
\hline 6 & 1000 & -40.5 & & $\begin{array}{c}- \\
0.0000 \\
3 \\
\end{array}$ & 27067 & -0.812 & & & & & & -812 & 32886 \\
\hline 7 & 1000 & -30.5 & & $\begin{array}{c}- \\
0.0000 \\
2\end{array}$ & 27350 & -0.547 & & & & & & -547 & 16684 \\
\hline 8 & 1000 & -20.5 & & $\begin{array}{c}- \\
0.0000 \\
1\end{array}$ & 27500 & -0.276 & & & & & & -276 & 5658 \\
\hline 9 & 1000 & -10.5 & & $\begin{array}{c}- \\
0.0000 \\
1\end{array}$ & 27500 & -0.276 & & & $\underset{07}{6,89 \mathrm{E}^{-}}$ & $\begin{array}{l}0,0 \\
00 \\
07 \\
\end{array}$ & & -276 & 2898 \\
\hline 10 & 100 & -0.5 & & 0 & - & 0.000 & & & & & & 0 & 0 \\
\hline 11 & 1900 & 9.5 & & $\begin{array}{c}0.0000 \\
1\end{array}$ & 26900 & 0.269 & & & & & & 511 & 4855 \\
\hline 12 & 1000 & 19.5 & & $\begin{array}{c}0.0000 \\
1 \\
\end{array}$ & 26900 & 0.269 & & & & & & 269 & 5246 \\
\hline 13 & 1000 & 29.5 & & $\begin{array}{c}0.0000 \\
2\end{array}$ & 26000 & 0.520 & & & & & & 520 & 15340 \\
\hline 14 & 1000 & 39.5 & & $\begin{array}{c}0.0000 \\
3\end{array}$ & 24867 & 0.746 & & & & & & 746 & 29467 \\
\hline 15 & 1000 & 49.5 & & $\begin{array}{c}0.0000 \\
3 \\
\end{array}$ & 24867 & 0.746 & & & & & & 746 & 36927 \\
\hline 16 & 1000 & 59.5 & & $\begin{array}{c}0.0000 \\
4\end{array}$ & 23575 & 0.943 & & & & & & 943 & 56109 \\
\hline 17 & 1000 & 69.5 & & $\begin{array}{c}0.0000 \\
5\end{array}$ & 22080 & 1.104 & & & & & & 1104 & 76728 \\
\hline 18 & 1000 & 79.5 & & $\begin{array}{c}0.0000 \\
5 \\
\end{array}$ & 22080 & 1.104 & & & & & & 1104 & 87768 \\
\hline 19 & 1000 & 89.5 & & $\begin{array}{c}0.0000 \\
6\end{array}$ & 20383 & 1.223 & & & & & & 1223 & 109459 \\
\hline 20 & 1000 & 99.5 & & $\begin{array}{c}0.0000 \\
7\end{array}$ & 18486 & 1.294 & & & & & & 1294 & 128753 \\
\hline \multirow[t]{2}{*}{21} & 7.07 & & $\begin{array}{c}101 . \\
5\end{array}$ & $\begin{array}{c}0.0000 \\
7 \\
\end{array}$ & & & $\begin{array}{c}72000.00 \\
0 \\
\end{array}$ & 5.04 & & & & 36 & 3617 \\
\hline & & & & & & & & & & & $\Sigma=$ & 232 & 1080523 \\
\hline
\end{tabular}

The minimum cross-section of the structure was previously taken at $100 \times 200(\mathrm{~h}) \mathrm{mm}$. In the calculation, we consider the work of only the fly-through part of the pergola. The calculation is carried out according to the procedure [20] on the basis of the nonlinear deformation 
model of concrete (Figures 6 - 9), and also taking the proportional dependence of the deformation of the reinforcing material.

The limiting moment, perceived by the cross section, is $\mathrm{M}_{\text {ult }}=1,41 \cdot 10^{6} \mathrm{Nmm}=1,41 \mathrm{kNm}$. The relative error in the calculations was $7 \%$. The crack resistance moment $\mathrm{M}_{\mathrm{crc}}=1.08 \cdot 10^{6}$ $\mathrm{Nmm}=1.08 \mathrm{kNm}$ (calculated with a relative error of $2 \%$ ). The limiting load, perceived by the cross section $\mathrm{M}_{\mathrm{crc}}=1.08 \mathrm{kNm}>\mathrm{M}=0.83$
$\mathrm{kNm}$. Tables 5 and 6 show the results of calculating the strength and crack resistance of the normal section: strength and crack resistance are provided.

Based on the results of calculating the structural strength of one element of a triangular shaped canopy of "sonic" pergola, the following textile-concrete construction is proposed to provide the required strength (Table 7).

Table 7. Textile-concrete construction.

\begin{tabular}{|c|c|c|c|}
\hline Denomination & Parameter & Number of layers & $\begin{array}{c}\text { Thickness of layer, } \\
\mathbf{m m}\end{array}$ \\
\hline Fine grained concrete & Table 2 & 7 & 40 \\
\hline Textile matrix & $\begin{array}{c}\text { AR-glass, } 120 \mathrm{~g} / \mathrm{m}^{2}, \\
\text { 2D }\end{array}$ & 6 & 1 \\
\hline
\end{tabular}

\section{CONCLUSIONS}

The proposed composition of high-performance textile-concrete and its construction can provide the necessary strength of the entire canopy of "sound" pergola and safety of operation. Composite materials with a set of different properties have become the main building materials of the 21 st century, which allows to expand the possibilities of modern architecture and open new boundaries of excellence. In this connection, the use of textiles-concrete in modern architecture as the main material for creating complex spatial forms is seen as particularly interesting.

The presented architectural concepts are the result of the first stage of the systemic study of the influence of one of the geofactors on a human within the framework of an architectural geonics, assuming the transdisciplinarity of the study. This stage formulates the problem of the need for mathematical calculations of geometric characteristics of the main sound translators - tubes. The formulation of this problem is reduced to the definition of the following:

- the length of the tube;

- diameter of the internal cavity;

- the size of the end of the tube;
- selection of pipe material with different sound reflectance;

- the effect of the wall thickness of the tube in the case of using the methods of creating wind musical instruments to extract sound harmonic oscillations in conditions of spontaneity of wind force and direction.

At the decision of this task the sound background will be controlled and therefore - directed. Calculations of "correcting" natural spontaneity will help create an alternative that mimics the sound frequencies of music, in the range of which a positive effect on a person occurs.

\section{REFERENCES}

1. Lesovik V.S. Arkhitekturnaya Geonika [Architectural Geonics]. // Zhilishchnoe stroitel'stvo, 2013, No. 1, pp. 9-12.

2. Lesovik V.S. Arkhitekturnaya Geonika. Vzglyad $\mathrm{V}$ budushchee [Architectural Geonics. Prospection]. // Vestnik VGASU. Seriya: Stroitel'stvo i arkhitektura, 2013, No. 31-1(50), pp. 131-136.

3. Pershina I.L. Arkhitekturnaya Geonika i Sreda Obitaniya Cheloveka [Architectural Geonics and Human Habitat]. // Inno- 
vatsiyni tekhnologiï $\mathrm{v}$ arkhitekturi i dizayni. Kharkivs'kiy natsional'niy universitet budivnitstva ta arkhitekturi, 2017, pp. pp.150-156.

4. Lesovik V.S., Pershina I.L. Opredelenie Spetsifichnosti Prostranstva V Arkhitekturnoy Geonike [Defining the Specificity of Space in Architectural Geonics]. // Aktual'nye voprosy arkhitektury i stroitel'stva: materialy Pyatnadtsatoy Mezhdunar. nauch.-tekhn. konf., Saransk 26-28 December 2016, Saransk: Izd-vo Mordov. un-ta, 2017, pp. 196-201.

5. Pershina I.L. Spetsificheskaya Sreda Geoniki - Vid Sredovogo Proektirovaniya $\mathrm{v}$ Arkhitekture [Specific Environment of Geonics - Type of Environmental Design in Architecture]. // Mezhdunarodnye akademicheskie chteniya RAACS "Bezopasnost' stroitel'nogo fonda Rossii. Problemy i resheniya", 29-30 November 2017, Kursk, KGU, pp. 220-225.

6. Lesovik V.S., Pershina I.L. Transdistsiplinarnost' Arkhitekturnoy Geoniki kak Opredelyayushchiy Faktor ee Sushchestvovaniya [Transdisciplinarity of Architectural Geonics as a Determining Factor of its Existence]. // Academia. Arkhitektura i stroitel'stvo, 2017, No. 4, pp. 107-110.

7. Rappaport

A.G. Kontseptsii Arkhitekturnogo Prostranstva [Concepts of Architectural Space]. Moscow, TSNTI, 1988.

8. Pershina I.L., Panchenko E.I. Proektnye Predlozheniya Sozdaniya Zvukovogo Prostranstva kak Kompilyatora Spetsificheskoy Sredy [Project Proposals for Creating a Sound Space as a Compiler of a Specific Environment]. // Mezhdunarodnyy onlayn kongress "Fundamental'nye osnovy stroitel'nogo materialovedeniya", Belgorod, BGTU im.V.G. Shukhova, 2017.

9. Lesovik V.S. Pershina I.L. Meditsinskiy Aaspekt Arkhitekturnoy Geoniki Vliyanie Zvukov na Cheloveka [The Medical Aspect of Architectural Geonics as the
Influence of Sounds on People]. // Vestnik fizioterapii i kurortologii, 2017, Vol. 23, No. 4, pp. 58-63.

10. Pershina I.L. O Transdistsiplinarnom Tandeme Meditsiny i Arkhitekturnoy Geoniki [About Transdisciplinary Tandem of Medicine and Architectural Geonics] // III Vserossiyskaya nauchnaya konferentsiya molodykh spetsialistov, aspirantov, ordinatorov "Innovatsionnye tekhnologii $\mathrm{v}$ meditsine: vzglyad molodogo spetsialista". Sektsiya: Mediko-profilakticheskie nauki, FGBOU VO RyazGMU Minzdrava Rossii, Ryazan', OOP UITT i OP, 2017, pp. 68-70.

11. Pershina I.L. Ob Ispol'zovanii dostizheniy Sredovoy Psikhologii v Arkhitekturnoy Geonike [On the use of the Achievements of Environmental Psychology in Architectural Geonics]. // IX Mezhdunarodnyy forum "Obrazovanie. Nauka. Proizvodstvo", 6-13 October 2017, Belgorod.

12. Lesovik V.S., Popov D.Yu., Glagolev E.S. Tekstil'-beton - Effektivnyy Armirovannyy Kompozit Budushchego [TextileConcrete is Effective Reinforced Composite of the Future], // Stroitel'nye materialy, 2017, No. 3, pp. 81-84.

13. Scherer S., Michler H., Curbach M. Brücken aus Textilbeton. Handbuch Brücken: Entwerfen, Konstruieren, Berechnen, Bauen und Erhalten, 2014, pp. 118-129.

14. Curbach M., Graf W., Jesse D., Sickert J. U., Weiland S. Segmentbrücke aus Textil-Bewehrtem Beton - Konstruktion, Fertigung, Numerische Berechnung. // Betonund Stahlbetonbau, 2007, No. 6(102), pp. 342-352.

15. Hegger J., Goralksi C., Kulas C. Schlanke Fußgängerbrücke aus Textilbeton Sechs-feldrige Fußgängerbrücke mit einer Gesamtlänge von $97 \mathrm{~m}$. // Beton- und Stahlbetonbau, 2011, No. 106, Heft 2, pp. 64-71.

16. Scholzen A., Chudoba R., Hegger J. Dünnwandiges Schalentragwerk aus textilbe-wehrtem Beton. Entwurf, Bemessung und baupraktische Umsetzung. // Beton- 
und Stahlbetonbau, 2012, Heft 11, pp. 767776.

17. Zagorodnyuk L.Kh., Lesovik V.S., Glagolev E.S., Elistratkin M.Yu., Lashina I.V., Masanin O.O. Ob"ektivnye Predposylki Perekhoda k Kompozitsionnym Vyazhushchim [Objective Prerequisites for the Transition to Composite Binders]. // "Naukoemkie tekhnologii i innovatsii", Sbornik dokladov Mezhdunarodnoy nauchno-prakticheskoy konferentsii, 2016, pp. 110-116.

18. Lesovik V.S., Strokova V.V., Krivenkova A.N., Khodykin E.I. Kompozitsionnoe Vyazhushchee s Ispol'zovaniem Kremnistykh Porod [Composite Binders with the Use of Siliceous Rocks]. // Vestnik Belgorodskogo gosudarstvennogo tekhnologicheskogo universiteta im. V.G. Shukhova, 2009, No. 1, pp. 25-27.

19. Kharkhardin A.N. Strukturnaya Topologiya Dispersnykh Naterialov [Structural Topology of Dispersed Materials]. Belgorod, Izd-vo BGTU, 2011.

20. SP 63.13330.2012 Betonnyye i zhelezobetonnyye konstruktsii. Osnovnyye polozheniya. Aktualizirovannaya redaktsiya SNiP 52-01-2003 [Concrete and reinforced concrete structures. Fundamentals. Updated version of SNiP 52-01-2003]. Moscow, Minregion Rossii, 2012.

\section{REFERENCES}

1. Лесовик В.С. Архитектурная геоника. // Жилищное строительство, 2013, №1, с. 9-12.

2. Лесовик В.С. Архитектурная геоника. Взгляд в будущее. // Вестник ВГАСУ. Серия: Строительство и архитектура, 2013, №31-1(50), c. 131-136.

3. Першина И.Л. Архитектурная геоника и среда обитания человека. // Інноваційні технології в архітектурі і дизайні. Харківський національний університет будівництва та архітектури, 2017, c. $150-156$.
4. Лесовик В.С., Першина И.Л. Определение специфичности пространства в архитектурной геонике. // Актуальные вопросы архитектуры и строительства: материалы Пятнадцатой Междунар. науч.-техн. конф., г. Саранск, 26-28 дек. 2016 г. - Саранск: Изд-во Мордов. унта, 2017, с. 196-201.

5. Першина И.Л. Специфическая среда геоники - вид средового проектирования в архитектуре. // Международные академические чтения РААСН «Безопасность строительного фонда России. Проблемы и решения», 29-30 ноября 2017 г. - Курск, КГУ г. Курск, 2017, с. 220-225.

6. Лесовик В.С., Першина И.Л. Трансдисциплинарность архитектурной геоники как определяющий фактор её существования. // Academia. Архитектура и строительство, 2017, №4, с. 107110.

7. Раппапорт А.Г. Концепции архитектурного пространства. - М.: ЦНТИ, 1988.

8. Першина И.Л., Панченко Е.И. Проектные предложения создания звукового пространства как компилятора специфической среды. // Международный онлайн-конгресс «Фундаментальные основы строительного материаловедения», БГТУ им. В.Г. Шухова, Белгород, 2017.

9. Лесовик В.С. Першина И.Л. Медицинский аспект архитектурной геоники влияние звуков на человека. // Вестник физиотерапии и курортологии, 2017, том 23, №4, с. 58-63.

10. Першина И.Л. О трансдисциплинарном тандеме медицины и архитектурной геоники. // III Всероссийская научная конференция молодых специалистов, аспирантов, ординаторов «Инновационные технологии в медицине: взгляд молодого специалиста». Секция: Медикопрофилактические науки, ФГБОУ ВО 
РязГМУ Минздрава России. - Рязань: ООП УИТТ и ОП, 2017, с. 68-70.

11. Першина И.Л. Об использовании достижений средовой психологии в архитектурной геонике. // IX Международный форум «Образование. Наука. Производство», 6-13 октября 2017 г. Белгород.

12. Лесовик В.С., Попов Д.Ю., Глаголев E.C. Текстиль-бетон - эффективный армированный композит будущего. // Строительные материалы, 2017, №3, с. 81-84.

13. Scherer S., Michler H., Curbach M. Brücken aus Textilbeton. Handbuch Brücken: Entwerfen, Konstruieren, Berechnen, Bauen und Erhalten, 2014, pp. 118-129.

14. Curbach M., Graf W., Jesse D., Sickert J. U., Weiland S. Segmentbrücke aus Textil-Bewehrtem Beton - Konstruktion, Fertigung, Numerische Berechnung. // Betonund Stahlbetonbau, 2007, No. 6(102), pp. 342-352.

15. Hegger J., Goralksi C., Kulas C. Schlanke Fußgängerbrücke aus Textilbeton Sechs-feldrige Fußgängerbrücke mit einer Gesamtlänge von $97 \mathrm{~m}$. // Beton- und Stahlbetonbau, 2011, No. 106, Heft 2, pp. 64-71.

16. Scholzen A., Chudoba R., Hegger J. Dünnwandiges Schalentragwerk aus textilbe-wehrtem Beton. Entwurf, Bemessung und baupraktische Umsetzung. // Betonund Stahlbetonbau, 2012, Heft 11, pp. 767776.

17. Загороднюк Л.Х., Лесовик В.С., Глаголев Е.С., Елистраткин М.Ю., Лашина И.В., Масанин О.О. Объективные предпосылки перехода к композиционным вяжущим. // «Наукоемкие технологии и инновации». Сборник докладов Международной научнопрактической конференции, 2016, с. 110-116.

18. Лесовик В.С., Строкова В.В., Кривенкова А.Н., Ходыкин Е.И. Композиционное вяжущее с использованием крем- нистых пород. // Вестник Белгородского государственного технологического университета им. В.Г. Шухова, 2009, №1, c. 25-27.

19. Хархардин А.Н. Структурная топология дисперсных материалов. - Белгород: Изд-во БГТУ, 2011.

20. СП 63.13330.2012 Бетонные и железобетонные конструкции. Основные положения. Актуализированная редакция СНиП 52-01-2003. - М.: Минрегион России, 2012.

Lesovik Valery Stanislavovich, Corresponding Member of the Russian Academy of Architecture and Construction Sciences, Full Professor, Dr of Sci. (Engineering)1; Head of the Department of Building Materials, Products and Structures; Belgorod Shukhov State Technological University; 308012, Russian Federation; Belgorod, Kostyukova Street, 46; phone: +7 (4722) 55-13-66,

E-mail: naukavs@mail.ru.

Pershina Irina Leonidovna, architect, postgraduate student; Department of Architecture and City Construction; Belgorod Shukhov State Technological University; 308012, Russian Federation; Belgorod, Kostyukova Street, 46; phone: +7 (915) 568-31-27,

E-mail: Irina.Pershina@mail.ru.

Popov Dmitry Yur'evich, engineer, postgraduate student; Department of Building Materials Science, Products and Structures, Belgorod Shukhov State Technological University; 308012, Russian Federation; Belgorod, Kostyukova Street, 46; phone: +7 (4722) 55-82-01,

E-mail: popov.dmitry412@yandex.ru.

Shevchenko Andrey Viktorovich, associate Professor, Ph.D (Engineering); Department of Urban Construction and economy, Belgorod Shukhov State Technological University; 308012, Russian Federation; Belgorod, Kostyukova Street, 46; phone: +7 (910) 225-35-85,

E-mail: andsheff@rambler.ru.

Лесовик Валерий Станиславович, членкорреспондент РААСН, профессор, доктор технических наук; заведующий кафедрой Строительного материаловедения, изделий и конструкций, Белгородский государственный технологический университет им. В.Г. Шухова; 308012, Российская Федерация, г. Белгород, ул. Костюкова, 46; тел. +7 (4722) 55-13-66, E-mail: naukavs@mail.ru. 
Першина Ирина Леонидовна, архитектор, аспирант; кафедра Архитектуры и градостроительства, Белгородский государственный технологический университет им. В.Г. Шухова; 308012, Российская Федерация, г. Белгород, ул. Костюкова, 46; тел. +7 (915) 56831-27, e-mail: rina.Pershina@mail.ru.

Попов Дмитрий Юрьевич, инженер, аспирант; кафедра Строительного материаловедения, изделий и конструкций, Белгородский государственный технологический университет им. В.Г. Шухова; 308012, Российская Федерация, г. Белгород, ул. Костюкова, 46; тел. +7 (4722) 55-82-01,

E-mail: popov.dmitry412@yandex.ru.

Шевченко Андрей Викторович, доцент, кандидат технических наук; кафедра Строительства и городского хозяйства, Белгородский государственный технологический университет им. В.Г. Шухова; 308012, Российская Федерация, г. Белгород, ул. Костюкова, 46; тел. +7 (910) 225-35-85,

E-mail: andsheff@rambler.ru. 